I wonder if the role of diffusion in the molecular biology of plant reproduction might have connected this coda more strongly to the earlier narrative.

The research is mostly thorough: Haw has picked up on subtleties often glossed over, such as the prescient role of Michael Faraday in advocating a correct reading of Brown's work, the correct early kinetic theory of the unfortunate John Waterston, who disappeared from science following its rejection, and the extraordinary timeliness of Einstein's molecular theory for the diffusion constant published earlier by the largely overlooked William Sutherland. But the reader has to stay alert - a cost of the narrative's unflagging pace is that people and places flash by all too quickly. I wish we had the time to get to know Perrin, and the shadowy figure of Brown himself, rather better.

Another aspect of the thirst for satisfying narrative is that history seems sometimes to be squeezed into the story's form, rather than the converse. So our sole representative of the middle ages is Hieronymous Bosch, whose portrayals of chaos conveniently prepare the stage for a sea change to order in the enlightened follow- ing act starring Galileo and Newton. The plot thickens with a return to calculated chaos in statistical mechanics, and so on. A case could be made more strongly for a highly ordered medieval theory of matter than for a chaotic one, and Galileo's corpuscular theory of matter in The Assayer in 1623 surely anticipates the underlying chaos of kinetic theory. But perhaps such complaints are churlish: a good yarn withers from too much of "on the other hand".

Such strong selection in historical interpretation, as well as some under-development of character, could well be the results of zealous editing with a younger lay readership in mind. In places the author gives the impression that he would have liked to say more. Perhaps the ambiguity in target readership is also reflected in the uneven style, which alternates ambitious alliteration with colloquialism (it was my first non-fiction read containing, as an entire sentence, "Not."). But these are pitfalls for all authors and publishers of 'popular science', and I would hope there is something for everyone in this highly enjoyable little book.

Tom McLeish is professor of polymer physics, University of Leeds, Leeds LS2 9JT, UK.

\title{
A Turkish revolution
}

\section{Turkey's Modernization: Refugees from Nazism and Atatürk's Vision by Arnold Reisman \\ New Academia: 2006. 572 pp. \$28}

\section{Martin Harwit}

Looking out of the window facing Prague's main railway station that evening, I saw a soldier in an unfamiliar uniform standing guard in the snow. The Germans had arrived. It was 15 March 1939, less than a week after my eighth birthday. By the end of the month, my parents, my sister and I were on a train to Istanbul. My father, whom the Germans had dismissed from his professorship at Charles University, had been offered the chair of biochemistry at Istanbul University. None of the Jewish members of our family who stayed behind survived the German occupation.

Our journey to Istanbul was not unique. Arnold Reisman's insightful book Turkey's Modernization documents how, starting in 1933, Turkey provided shelter to more than a hundred eminent European academics and their families, all victims of Nazi persecution. The task of the professors was to initiate the country's first modern university and train a generation of young Turkish scholars able to further expand higher education.

Two men spearheaded the drive to establish Istanbul University. The vision was provided by Mustafa Kemal Atatürk, who founded the modern Turkish Republic on the shards of a crumbled Ottoman empire. As a young military officer in the First World War, Mustafa
Kemal had become a hero to his countrymen, first for repulsing the Allies at the Dardanelles, and later for recapturing the territories that define modern Turkey today. Once in power, he decreed that Turkey would discard its Ottoman past and become a modern state modelled on European lines. A new constitution and newly enacted laws affected every aspect of life.

Men were prohibited from wearing the traditional fez. Women were forbidden from hiding their faces behind veils. Polygamy was abolished. Everyone had to adopt a family name; for himself, Mustafa Kemal chose 'Atatürk' - father of the Turks. To eradicate widespread illiteracy, every child now had to be schooled. Arabic script was outlawed and replaced by a

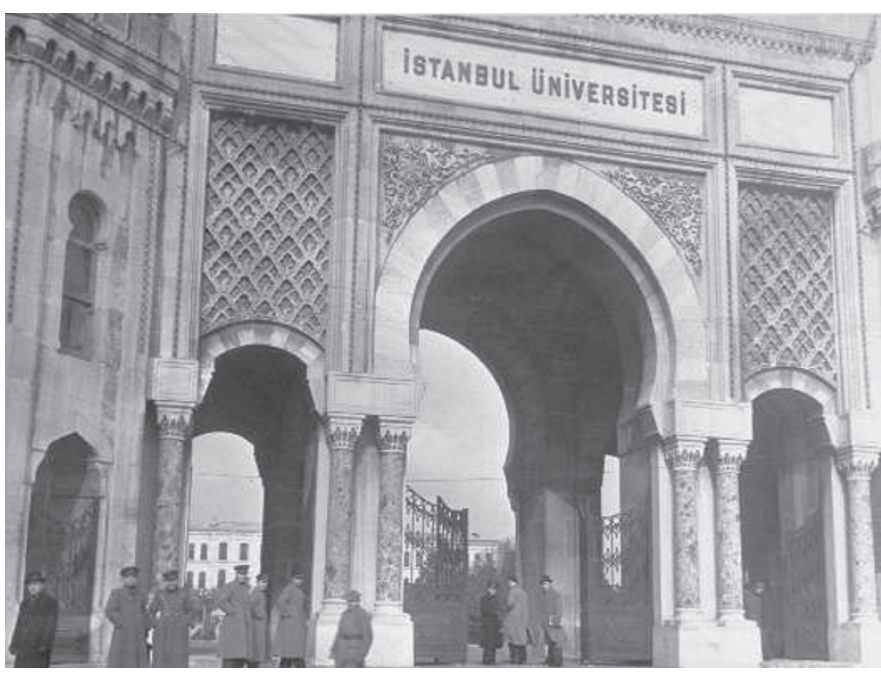

Roman alphabet. The caliphate - the office of the head of the Muslim religion - was dismissed to make Turkey secular. And on 31 July 1933, to complete the transformation, Atatürk closed down Istanbul's institution of traditional higher learning, the darülfünun, dismissing the entire faculty. On the same premises, the very next day, he installed a new Western-style university with a distinguished faculty.

Assembling this faculty required a second, quite different architect, one cognizant of scholarship and competence. That man was Philipp Schwartz, a Hungarian-born pathologist who had been dismissed by the Nazis from his position in Frankfurt and had fled to Switzerland. There he had founded the Notgemeinschaft Deutscher Wissenschaftler im Ausland, which compiled and maintained a roster of leading scholars seeking to escape Nazi oppression. Schwartz persuaded the Turkish government that his organization could staff an entire university - so many outstanding academics were being persecuted that they could select the very best.

As Reisman recounts, Istanbul University embraced a wide range of disciplines, although the heart of the university was the medical faculty. Foreign academics had to start at the most elementary level. Before medicine could be taught, a Turkish medical vocabulary had to be devised. Only then could the first modern texts be written in Turkish and medical students taught in their own language. The nation was in dire need of physicians, especially in remote regions of Anatolia. The university trained thousands of young doctors who, in exchange for free schooling, were obliged to provide medical services in understaffed parts of the country for several years after graduation.

The book captures the spirit of the times, the resistance the foreign scholars faced as they sought to modernize Turkey's institutions of higher education, the worries brought on by the war, and the family outings in which foreigners often compared notes and tried to laugh at the sometimes ludicrous problems they faced. What remains with me from these outings, so many years later, is the interest the 
professors took in us children. Reisman's richly illustrated book recalls this aspect of family life in the community.

Looking back, some seventy years later, how should we judge the impact of the European academics? The draconian measure of closing the darülfünun to create Istanbul University left deep wounds. The 2006 Nobel laureate in literature, Orhan Pamuk, remarks in his book Istanbul (Alfred A. Knopf, 2005) on the unjust dismissal of traditional Ottoman scholars. His concern is the loss of the nation's identity in the
Atatürk reforms. Although distancing Turkey from its Ottoman past, the modernization has not yet led to Turkey's full acceptance as a Western nation.

Nevertheless, as Reisman notes, Istanbul University became established almost overnight and the foreign professors continued to educate Turkish students from 1933 until about 1948. By then a strong academic community had been built with talented young Turks. Dozens of new universities began springing up across the country, and the assistance of the foreign professors, many of whom went on to productive careers elsewhere, was no longer needed.

Today, Turkish names appear on articles in leading international journals, showing how the vision of one man and the organizational acumen of another laid a foundation on which Turkey has continued to build.

Martin Harwit is former director of the National Air and Space Museum, Washington DC 20560, and is emeritus professor of astronomy at Cornell University, Ithaca, New York 14853, USA.

\section{Gene expression}

\section{Sarah Jacobs mutates genetic information into art.}

\section{Martin Kemp}

How can artists possibly confront the excruciating complexity of the human genome - or any genome for that matter? There are just too many of the letters $C, G, A$ and $T$. It is possible, however, to make some general artistic statements about the human genome project and its implications, and about genetic engineering as a whole. But it is all too easy to sink to the level of the 'Frankenstein food' headline that appeared in the British newspaper the Daily Mail on 13 February 1999.

Sarah Jacobs shows that the complexity can be tackled head on. She has a record of working with the blank poetics of modern scientific discourse, with its studied eschewing of personal expression. Her 92-page e-book Deciphering Human Chromosome 16: We Report Here is studded throughout with phrases from the original article, 'The sequence and analysis of duplication-rich human chromosome 16' (Nature 432, 988-994; 2004). "We report here" is one of these, together with "We observed" (of course), "Here we describe", "We constructed", "We adopted a strategy", "We then eliminated", "Finally we identified", and so on. Isolated, phrases that are so much part of scientific normality assume the quality of an incantation.

After the Nature article was published, Jacobs googled such terms as "human chromosome 16", "chromosome 16 book" and "chromosome 16 expression". She even searched for odd combinations, such as "chromosome 16" + "Saddam Hussein".
She sifted out around 250 website links on the basis of what appeared intellectually or intuitively interesting and "looked good". The e-book proceeds through simple pages of the incantatory phrases interspersed with coloured lower-case overprinting of the website links with fragments of their text and numbers from the original article in large capitals (see the page shown below).

The result is a doggedly

the original article. They are accompanied by enigmatic fragments from the websites.

Given the vagaries of the production process, each index assumes an individual character. The letters C, G, A and T on every left-hand page are bled to the page borders, and their visible expression on the unbound edge of the closed book varies unpredictably as the result of minute variations in the trimming process.

The report and the index are odd, difficult, perplexing, suggestive and strangely beautiful - and awesome in their numerical persistence. Jacobs has created something drawn directly from the science and its diffusion, using the tools of a bibliographer. Yet the result subverts the science in the direction of chaos and cacophony. The effect is analogous to the way that the particularity of each individual person seems to confound the overwhelming similarity of our genetic constitutions.

At least, this is one possible

accumulated 'report' on the incredibly rapid Internet diffusion of the knowledge in standard and bizarre forms. The contents are subject to constant mutation, so every six months Jacobs takes screen shots to document the changes.

To accompany the report, Jacobs has now issued an 'index' as a print-on-demand book, with a fixed form of 552 pages (www.informationasmaterial.com). Against the background of the CGAT permutations, the accumulated number of characters is remorselessly spelt out, up to "Sixteen million five hundred and forty-one thousand and nine hundred" - still some way short of the roughly 80 million base pairs noted in interpretation. There are others. Jacobs is, I suspect, resisting any closed or dominant reading. And therein lies the difference between the original Nature article and Jacobs' visual play. The scientific exposition provides as little latitude for alternative readings as possible, whereas Jacobs provides a field for interpretative flexibility that triggers thoughts and insights of an unexpected nature - unexpected, perhaps, even to the author herself.

Martin Kemp is professor of the history of art at the University of Oxford, Oxford OX1 1PT, UK. His new book, Seen | Unseen, is published by Oxford University Press. 